\title{
Analisis Kompetensi Guru Non Sertifikasi Pendidik Dalam Menanamkan Nilai-nilai Religius Pada Mata Pelajaran Pendidikan Agama Islam di Madrasah Aliyah An-Nur Rambipuji
}

\author{
Khoirul Rochim \\ Mahasiswa FTIK, UIN Kiai Haji Achmad Siddiq Negeri Jember \\ Email: khoirulrochim28@gmail.com \\ M. Khoirul Hadi Al-Asy'ari \\ Fakultas Syariah, UIN Kiai Haji Achmad Siddiq Negeri Jember \\ Email:Arimoh16@gmail.com
}

DOI: https://doi.org/10.21154/sajiem.v2i2.62

\begin{abstract}
Kompetensi guru sebagai kemampuan yang harus dimiliki dalam mengemban tugas sebagai pendidik, sebab ini sebagai syarat dalam mengemban tugas dalam pelaksanaan pembelajaran. sertifikasi pendidik ini sebagai syarat dalam menentukan profesionalitas seorang pendidik. Sehingga seorang pendidik diharuskan mempunyai sertifikat pendidik dalam mengemban tugas profesionalitas pendidik. Terdapat asumsi bahwa seorang guru non sertifikasi pendidik belum dikatakan sebagai profesionalitas pendidik, karena tidak mempunyai sertifikat pendidik. Tujuan dalam penelitian ini, bagaiman konsep kompetensi guru?, bagaiman penanaman nilai-nilai religius? Serta bagaiman penanaman nilai-nilai religius dalam pendidik agama islam?. Metode dalam penelitian ini menggunakan penelitian kualitatif dengan jenis penelitian study kasus. Teknik dalam pengumpulan data yang digunakan menggunakan observasi, wawancara dan dokumentasi. Analisis data ini sebagai proses dan menyusun sistematis data yang diperoleh dari teknik pengumpulan data, dengan begitu analisis data yang digunanakan dalam penelitian ini
\end{abstract}


menggunakan analisis kualitatif model, Miles, huberman dan Saldana yakni, kondensasi data, penyajian data, dan penarikan kesimpulan. Penelitian ini memperoleh kesimpulan bahwa, dalam penanaman nilai-nilai religius peserta didik dianjurkan sholat dhuha berjamaah. Dengan tujuan peserta didik dapat membiasakan shalat dhuha diwaktu pagi. sehingga diharapkan semuanya dapat menanamkan jiwa atau kedisiplinan bahwa shalat dhuha sebagai bentuk atas rasa syukur yang diberikan kepada Allah SWT. Serta membiasakan juz 30 yang dibaca, ini bertujuan agar membaca dan menghafal dapat terjalin dengan seutuhnya dalam diri peserta didik. Artinya menanamkan membaca dan menghafal ayat dan makna Al-Quran memberikan daya motivasi dalam belajar dengan bersungguh-sungguh. penanaman nila-nilai religius dalam kegiatan ${ }_{3} \mathrm{~S}$ (senyum,sapa,salam), yang diprogramkan guru pendidikan agama Islam. kebiasaan ini diharapkan menjadi budaya nantinya, yang selalu tertanam dalam jiwa peserta didik baik di sekolah maupun luar sekolah.

Kata Kunci: Kompetensi Guru, Nilai-Nilai Religius, Penanaman Nilai-Nilai Religius Mapel PAI

\section{Pendahuluan}

Munculnya berbagai fenomena dehumanisasi dan demoralisasi dalam kehidupan bermasyarakat, menjadikan sebuah tandadimana tatanan sosial masyarakat baik secara langsung maupun tidak langsung mulai dikesampingkan bahkan diabaikan yang pada akhirnya individu tidak jarang melanggar nilai nilai dasar kemanusiaan itu sendiri. Hal tersebut telah memicu terjadinya krisis nilai dan moral generasi bangsa.

Melihat kenyataan yang terjadi, Muslich, ${ }^{1}$ menegaskan bahwaDunia pendidikan telah melupakan tujuan utama pendidikan, yaitu mengembangkan pengetahuan, sikap,dan keterampilansecara simultan dan seimbang. Dunia pendidikankita telahmemberikan porsi yang sangat besar untuk pengetahuan,tetapimelupakan pengembangan sikap/nilai dan perilaku dalampembelajarannya. Dunia pendidikan saat ini dalam prosesnyaterkesan lebih mementingkan aspek kognitif semata.

Menurut Zubaidi, ${ }^{2}$ krisis yang melanda peserta didik/mahasiswa yang terjadi menjadikan indikator bahwa begitu banyak manusia Indonesia yang tidak koheren antara ucapan dan tindakannya sehingga terjadi split

${ }^{1}$ Mansur Muslich, Pendidikan Karakter, Menjawab Tantangan Krisis Multidimesional, (Jakarta: PT Bumi Aksara, 2011), 17.

2ZZubaidi, Desain Pendidikan Karakter, (Jakarta: Prenada Media Group, 2011 ), 2. 
personality. Kondisi tersebut, diduga berawal dari apa yang dihasilkan oleh dunia pendidikan.

Banyak permasalahan yang muncul pada masyarakat bangsa Indonesia, tidak terkecuali dengan kasus minimnya karakter yang dimiliki oleh peserta didik. Seperti karakter religius, rasa kurang percaya diri, dan kurang disiplin. Padahal rasa religius, percaya diri dan disiplin merupakan salah satu pilar karakter yang harus ditanamkan kepada peserta didik. Akhir-akhir ini bangsa kita sedang mengalami krisis rasa religius bisa dilihat dari perilaku anak seusia sekolah membunuh orang tua kandungnya sendiri gara-gara tidak menuruti permintaannya. Selain itu rasa percaya diri penduduk di Indonesia kurang, dapat dilihat dari lebih banyak penduduk yang bekerja di bawah pimpinan warga asing daripada mencoba untuk membuka usaha secara mandiri pada keahlian yang dimilikinya.

Nilai religius merupakan salah satu nilai karakter yang dijadikan sebagai sikap dan perilaku yang patuh dalam melaksanakan ajaran agama yang dianut, toleran terhadap pelaksanaan ibadah agama lain, dan hidup rukun dengan pemeluk agama lain. Karakter religius ini sangat dibutuhkan oleh siswa dalam menghadapi perubahan zaman dan degradasi moral seperti saat ini. Dalam hal ini peserta didik diharapakan mampu memiliki dan berperilaku dengan ukuran baik dan buruk yang didasarkan pada ketentuan dan ketetapan agama.Melalui nilai-nilai karakter religius dengan melalui integrasi dalam mata pelajaran. Dalam konteks ini mata pelajaran yang memfokuskan untuk menanamkan karakter religius yaitu pada mata pelajaran Pendidikan Agama Islam. Namun demikian, dalam setiap mata pelajaran guru berhak menyisipkan pendidikan karakter pada peserta didik.

Kompetensi pada dasarnya merupakan deskripsi tentang apa yang dapat dilakukan seseorang dalam bekerja, serta apa wujud dari pekerjaan tersebut yang dapat terlihat. Untuk dapat melakukan suatu pekerjaan, seseorang harus memiliki kemampuan dalam bentuk pengetahuan, sikap dan ketrampilan yang relevan dengan bidang pekerjaannya. ${ }^{3}$ Seseorang disebut kompeten dalam bidangnya jika pengetahuan, ketrampilan dan sikapnya, serta hasil kerjanya sesuai standar (ukuran) yang ditetapkan dan atau diakui oleh lembanganya pemerintah. ${ }^{4}$

Dalam Undang-undang Republik Indonesia Nomor 14 Tahun 2005 tentang Guru dan Dosen, dijelaskan bahwa:

${ }^{3}$ Suyanto dan Asep Jihad, Menjadi Guru Profesional: Strategi Meningkatkan Kualifikasi dan Kualitas Guru di Era Globalisasi, (Jakarta: Erlangga.2013), 39.

${ }^{4}$ Jejen Musfah, Peningkatan Kompetensi Guru : Melalaui Pelatihan dan Sumber Belajar Teori dan Praktik,(Jakarta: Kencana, 2012), 28. 
"Kompetensi adalah seperangkat pengetahuan, keterampilan, dan perilaku yang harus dimiliki, dihayati, dan dikuasai oleh guru atau dosen dalam melaksanakan tugas keprofesionalan". ${ }^{5}$

Sedangkan dalam Undang-undang Guru dan Dosen No.14/2005 Pasal 10 ayat 1 Dan Peraturan Pemerintah No.19/2005 pasal 28 ayat 3 yang dikuti Jamil dalambukunya dinyatakan bahwa kompetensi guru meliputi kompetensi pedagogik, kompetensi kepribadian, kompetensi sosial dan kompetensi profesional. ${ }^{6}$

Sertifikasi guru merupakan proses pemberian sertifikat pendidik kepada guru sertifikat pendidik diberikan kepada guru yang telah memenuhi standar profesional guru. Sehingga guru profesional sebagai syarat mutlak untuk menciptakan sistem dan praktik pendidikan yang berkuasa. Dengan begitu, sertifikat pendidik disebutkan bahwa, sebuah sertifikat yang ditandatangani oleh perguruan tinggi penyelenggara sertifikasi sebagai bukti formal pengakuan profesionalitas guru yang diberikan kepada guru sebagai tenaga profesional.

Dengan demikian dikatakan guru profesional bahwa, seorang guru harus mempunyai sertifikat pendidik yang telah ditandatangani oleh perguruan tinggi yang menyelenggarakan sertifikasi pendidik, sehingga menjadi bukti bahwa seorang guru dikatakan profesional dengan menguasai kompetensi pedagogik, kepribadian, sosial dan profesional. Lantas bagaimana guru yang belum sertifikasi pendidik, apakah bisa dikatan sebagai guru profesional dan menguasai keempat kompetensi yang sudah ditetapkan dalam implementasi pembelajaran. Sehingga dari pernyataan diatas, penulis mengangkat artikel ini dengan judul " Analisis Kompetensi guru Non Sertifikasi Pendidik Dalam Menanamkan Nilai-Nilai Religius Pada Mata Pelajaran Pendidikan Agama Islam di Madrasah Aliyah An-Nur Rambipuji".

\section{Metode Penelitian}

Penelitian ini menggunakan pendekatan penelitian kualitatif deskriptif, sedangkan jenis penelitian yang digunakan adalah penelitian study kasus (Case Study). Lokasi dalam penelitian ini bertempat di Madrasah An-Nur Rambipuji yang terletak di Jalan Argopuro No. 47 Rambigundam Rambipuji. Informan dalam penelitian ini yakni guru non sertifikasi pendidikan agama Islam dalam penanaman nilai-nilai pada Mata pelajaran pendidikan agama Islam, kepala sekolah dan siswa. Teknik dalam pengumpulan data yang

${ }^{5}$ E. Mulyasa, Standar Kompetensi dan Sertifikasi Guru, (Bandung: PT Remaja Rosdakarya,2013), 25.

${ }^{6}$ Jamil Suprihatiningkrum, Guru Profesional : Pedoman Kinerja, Kualifikasi E Kompetensi Guru, (Yogyakarta: Ar-Ruzz Media.2014), 100.

${ }^{7}$ Lexy Moleong, Metodologi Penelitian Kualitatif (Bandung: PT Remaja Rosdakarya, 2010), 6. 
digunakan menggunakan observasi, wawancara dan dokumentasi. ${ }^{8}$ Sedangkan analisis data ini sebagai proses dan menyusun sistematis data yang diperoleh dari teknik pengumpulan data, dengan begitu analisis data yang digunanakan dalam penelitian ini menggunakan analisis kualitatif model, Miles, huberman dan Saldana yakni, kondensasi data, penyajian data, dan penarikan kesimpulan. ${ }^{9}$ Serta keabsahan data yang digunakan untuk memeriksa validitas dalam mengetahui tingkat kepercayaan yang dicapai sehingga menunjukkan hasil yang terpercaya dengan temuan tersebut, maka keabsahan data ini menggunakan triangulasi sumber dan triangulasi teknik. ${ }^{10}$

\section{Pembahasan}

\section{Konsep Kompetensi Guru}

Kompetensi guru diartikan dengan kemampuan terhadap suatu tugas tanggung jawab (mengajar dan mendidik), baik dalam keterampilan, sikap dan apresiasi yang diperlukan untuk mensukseskan kelancaran dalam pendidikan yang dilaksanakan. Dengan demikian kompetensi tidak hanya berkenaan dengan kemampuan guru dalam menyajikan pelajaran di depan kelas, melainkan termasuk keterampilan guru dalam mendidik dan menanamkan sikap tanggung jawab yang baik pada saat Belajar."

Dalam Undang-undang Guru dan Dosen No.14/2005 Pasal 10 ayat 1 Dan Peraturan Pemerintah No.19/2005 pasal 28 ayat 3 yang menyatakan bahwa, kompetensi guru meliputi kompetensi pedagogik, kompetensi kepribadian, kompetensi sosial dan kompetensi profesional. ${ }^{12}$

Hamzah B. Uno dalam Imron Fauzi mengemukakan bahwa kompetensi merupakan karakterisitik yang sering dilakukan pada seseorang dan menjadi metode berperilaku dan berfikir dalam segala situasi, dan berlangsung pada periode waktu yang lama. Dari pendapat tersebut dapat difahami bahwa kompetensi menunjuk pada kinerja seseorang dalam suatu amanah/tanggung jawab yang dibebankan pada individu yang dapat dilihat dari pikiran, sikap, dan tindakan. ${ }^{13}$

${ }^{8}$ Sugiyono, Metode Penelitian Pendidikan Pendekatan Kuantitatif, Kualitatif, Dan RED (Bandung: Alfabeta, 2014), 308.

${ }^{9}$ Miles, Huberman dan Saldana,, Qualitative Data Analysis (America: SAGE Publications, 2014), 12.

${ }^{10}$ Alfiatu Solikah, Strategi Peningkatan Mutu Pembelajaran Pada Sekolah Unggulan, (Yogyakarta: CV Budi Utama, 2019), 29-31.

${ }^{11}$ Feralys Novauli. M, "Kompetensi Guru Dalam Peningkatan Prestasi Belajar Pada SMP Negeri Dalam kota Banda Aceh”, Jurnal Administrasi Pendidikan 3, no. 1 (februari, 2015): 48.

${ }^{12}$ Depatemen Pendidikan Nasional, Undang-Undang Republik Indonesia, No. 14 Tahun 2005 Tentang Guru dan Dosen, 2006.

${ }^{13}$ Imron Fauzi, Etika Profesi Keguruan, (Jember: IAIN Jember Press,2017), 144. 
Jadi dapat ditarik kesimpulanm bahwa penjelasan kompetensi guru adalah kemampuan yang dimiliki oleh seseorang yang mempunyai bakat, sehingga menjadi profesi dalam kemampuan mengajar dan memiliki kinerja yang baik serta bertanggung jawab dalam melaksanakan kegiatan profesinya. Kompetensi yang harus dimiliki seorang guru dapat bagi sebagai berikut:

\section{1) Kompetensi Pedagogik}

Kompetensi peagogik merupakan merupakan kemampuan teknis dalam menjalankan tugas/ tanggung jawab sebagai pendidik, pengajar dan pembimbing dalam melaksanakan proses pembelajaran yang dilakukanya. Sehingga Kompetensi pedagogik dapat ditarik kesimpulan bahwa, kemampuan guru yang berkenaan dengan tanggung jawab dalam pembelajaran terhadap peserta didik dan pengelolaan pembelajaran yang mendidik dan dialogis. Secara substantif, kompetensi ini mencakup kemampuan pemahaman terhadap peserta didik, perancangan dan pelaksanaan pembelajaran, evaluasi hasil belajar, serta pengembangan peserta didik untuk mengaktualisasikan berbagai potensi yang dimilikinya. ${ }^{14}$

Sedangkan menurut E Mulyasa kompetensi pedagogik merupakan kemampuan guru dalam mengelola pembelajaran terhadap peserta didik yang meliputi pemahaman peserta didik, perancangan dan pelaksanaan pembelajaran, evaluasi hasil belajardan pengembangan peserta didik untuk mengaktualisasikan berbagai potensi yang dimilikinya. ${ }^{15}$

2) Kompetensi Profesional

Guru harus memiliki pengetahuan yang luas berkenaan dengan bidang studi (subjek matter) yang akan diajarkan serta penguasaan didaktik metodik dalam arti memiliki pengetahuan konsep teoritik, mampu memilih model, strategi, dan metode yang tepat serta mampu menerapkanya dalam kegiatan pembelajaran. Dengan demikian, Guru harus mempunyai pengetahuan yang luas dalam bidang studi yang diajarkan dengan tujuan pembelajaran dapat terealisasi terhadap peserta didik dengan maksimal. ${ }^{16}$

Kompetensi Profesional merupakan kemampuan guru dalam penguasaan materi pelajaran secara luas dan mendalam. Proses belajar dan hasil belajar peserta didik bukan saja ditentukan oleh sekolah, pola, struktur, dan isi kurikulumnya, akan tetapi sebagian besar ditentukan oleh kompetensi guru yang mengajar dalam membimbing peserta didik. Guru yang berkompeten akan lebih mampu menciptakan lingkungan belajar yang efektif, menyenangkan, dan akan lebih mampu mengelola kelasnya,

${ }^{14}$ J.B Situmorang dan Winarno, Pendidikan Profesi dan Sertifikasi Pendidik, (Klaten: Macanan Jaya Cemerlang,2008), 23.

${ }^{15}$ E. Mulyasa, Standar Kompetensi dan Sertifikasi Guru, (Bandung: PT Remaja Rosdakarya, 2013), 75.

${ }^{16}$ Imron Fauzi, Etika Profesi Keguruan, (Jember: IAIN Jember Press,2017), 151. 
sehingga belajar peserta didik berada pada tingkat optimal. ${ }^{17}$ Maka kompetensi profesional guru berpacu pada kemampuan penguasaan materi yang dimilikinya secara luas, sehingga guru dapat menciptakan suasana belajar yang dapat memberikan pemahaman materi dengan mudah di fahami terhadap peserta didik.

3) Kompetensi Kepribadian

Dalam PP No. 19 tahun 2005 jo PP No. 32 tahun 2013, pasal 28 (3) butir bm dikemukakan bahwa yang dimaksud dengan kompetensi kepribadian adalah kemampuan kepribadian yang mantap, stabil, dewasa, arif dan berwibawa, menjadi teladan bagi peserta didik dan berakhlak mulia.

Kusnandar dalam bukunya Imron Fauzi menyatakan bahwa, kompetensi kepribadian adalah perangkat perilaku/tindakan yang berkaitan dengan kemampuan individu yang mencerminkan layaknya seorang guru dalam mewujudkan dirinya sebagai pribadi yang mandiri untuk melakukan transformasi diri dalam pengetahuan, identitas diri dan pemahaman diri. ${ }^{18}$

Kompetensi kepribadian merupakan kemampuan personal yang mencerminkan kepribadian yang mantap, stabil, dewasa, arif dan wibawa, menjadi teladan bagi peserta didik, dan berakhlak mulia. Kepribadian guru sangat kuat pengaruhnya terhadap tugasnya sebagai pendidik. Kewibawaan guru ada dalam kepribadiannya. Sulit bagi guru mendidik peserta didik untuk disiplin kalau guru yang bersangkutan tidak disiplin. Peserta didik akan menggugu dan meniru gurunya sehingga apa yang dikatakan oleh guru seharusnya sama dengan tindakannya. Guru yang jujur dan tulus dalam menjalankan tugasnya sebagai pendidik berbeda dengan guru yang mengajar karena tidak ada pekerjaan lain. Peserta didik dengan mudah membaca hal tersebut. ${ }^{19}$

4) Kompetensi Sosial

Menurut Buchari Alma, kompetensi sosial adalah kemampuan guru dalam berkomunikasi dan berinteraksi secara efektif dengan lingkungan sekolah maupun diluar lingkungan sekolah. ${ }^{20}$ Dalam PP No. 19 tahun 2005 jo PP No. 32 tahun 2o13pasal 28 (3) butir d, dikemukakn bahwa yang dimaksud kompetenso sosial adalah kemampuan guru dari sebagian masyarakat untuk berkmonikasi dan bergaul secara efektif dengan peserta

\footnotetext{
${ }^{17}$ Feralys Novauli. M, "Kompetensi Guru Dalam Peningkatan Prestasi Belajar Pada SMP Negeri Dalam kota Banda Aceh”, Jurnal Administrasi Pendidikan 3, no. 1 (februari, 2015): 52.

${ }^{18}$ Imron Fauzi, Etika Profesi Keguruan, (Jember: IAIN Jember Press,2017), 147.

${ }^{19}$ J.B Situmorang dan Winarno, Pendidikan Profesi dan Sertifikasi Pendidik, (Klaten: Macanan Jaya Cemerlang,2008), 21.

${ }^{20}$ Agus Wibowo dan Hamrin, Menjadi Guru Berkarakter: Strategi Membangun Kompetensi dan Karakter Guru, (Yogyakarta: Pustaka Pelajar, 2012), 124.
} 
didik, sesama pendidik, tenaga kependidikan, orang tua/wakil peserta didik dan masyarakat sekitar. ${ }^{21}$

Inti dari kompetensi sosial terletak pada komunikasi, tetapi komunikasi yang dimaksud adalah komunikasi yang efektif. Komunikasi dapat diartikan sebagai suatu proses saling mempengaruhi antar manusia. Komunikasi juga merupakan keseluruhan dari pada perasaan, sikap dan harapan-harapan yang disampaikan baik secara langsung atau tidak langsung, baik yang dilakukan secara sadar atau tidak sadar karena komunikasi merupakan bagian integral dari proses perubahan. ${ }^{22}$ sehingga komunikasi yang baik dalam pembelajaran menjadi suatu pokok penting dalam menyampaikan isi materi sesuai dengan bidang studi yang dimilikinya terhadap peserta didi. Komunikasi yang baik juga akan menimbulkan komunikasi baik pula pada peserta didik, sehingga materi pembelajaran dapat difahami dengan mudah dan menyeluruh.

\section{Penanaman Nilai-nilai Religius}

Penanaman secara etimologis berasal dari kata "tanam" yang berarti menabur benih, yang semakin jelas jika mendapatkan awalan dan akhirat menjadi "penanaman" yang berarti proses, cara, perbuatan menanam, menanami atau menanamkan. ${ }^{23}$ Sedangkan nilai adalah prinsip atau hakikatnya yang menentukan harga atau nilai dan makna bagi sesuatu baik tindakan maupun pengalaman. Nilai adalah suatu perangkat keyakinan atau perasaan yang diyakini sebagai suatu identitas yang memberikan corak yang khusus kepada pola pemikiran, perasaan, keterikatan maupun prilaku. ${ }^{24}$

Fathurrahman berpendat bahwa, nilai-nilai religious terbagi menjadi 5 , sebagai berikut: ${ }^{25}$

1. Nilai Ibadah

Secara istilah berarti khidmat kepada Tuhan, dengan mengerjakan perintah-Nya dan menjauhi segala laranganNya. Ibadah adalah aktivitas manusia kepada tuhan yang diimplementasikan dalam kegiatan seharihari dengan ketaatan yang penuh ikhlas dalam menjalankan. misalnya,

\footnotetext{
${ }^{21}$ Imron Fauzi, Etika Profesi Keguruan, (Jember: IAIN Jember Press,2017), 152.

${ }^{22}$ Imron Fauzi, Etika Profesi Keguruan, (Jember: IAIN Jember Press, 2017), 153.

${ }^{23}$ Pusat Bahasa Departemen Pendidikan Nasional, Kamus Besar Bahasa Indonesia, (Jakarta: Balai Pustaka, 2003), 1134.

${ }^{24}$ Abu Ahmad dan Noor Salim, Dasar-Dasar Pendidikan Agama Islam, (Jakarta: Bumi Aksara, 2008), 202.

${ }^{25}$ Faturrohman, Budaya Religius Dalam Peningkatan Mutu Pendidikan, Tinjauan Teoritik dan Praktik Konstekstualisasi Pendidikan Agama Di Sekolah, (Yogyakarta: Kalimemedia, 2015), 6o-69.
} 
sholat, puasa, zakat dan lain sebagainya. ${ }^{26}$ Ibadah baik umum maupun khusus merupakan konsekuensi dan implikasi dari keimanan terhadap Allah SWT yang tercantum dalam dua kalimat syahadat."asyhadu alla ilaaha illallaah, waasyhadu anna Muhammadar Rasulullah. Bahwa ibadah adalah ketaatan manusia kepada Tuhan yang diimplementasikan dalam kegiatan sehari-hari.

2. Nilai Akhlak

Akhlak merupakan bentuk jama' dari khuluq, artinya perangai, tabiat, rasa malu dan adat kebiasaan. Akhlak merupakah segala hal yang melekat pada jiwa manusia yang darinya timbul perbuatan-perbuatan yang bermanfaat pada orang lain tanpa memikirkan apapun. ${ }^{27}$ Sebagaimana $\mathrm{Al}-$ Ghazali mengungkapkan tentang akhlak adalah sifat yang tertanam dalam jiwa yang menumbuhkan perbuatan perbuatan dengan wajar dan mudah, tanpa memerlukan pikiran dan pertimbangan lagi. ${ }^{28}$ Ajaran Islam sangat sangat menekankan tentang pembentukan akhlak yang mulia, dalam salah satu hadisnya Rasulullah SAW bersabda, yang artinya: "Bahwasanya aku diutus (Allah) untuk menyempurnakan keluhuran budi pekerti". (H.R. Ahmad).

Ruang lingkup kajian akhlak meliputi: akhlak yang berhubungan dengan Allah, diri sendiri, keluarga, masyarakat dan lingkungan. Contoh akhlak yang berhubungan dengan Allah seperti bersyukur, taqwa, berdo'a. Akhlak terhadap diri sendiri seperti sabar, qanaah atau merasa cukup dengan apa yang sudah ada. Akhlak terhadap keluarga seperti berbuat baik kepada kedua orang tua, saudara dan kerabat. Akhlak di masyarakat seperti tolong-menolong, adil dan musyawarah. dan akhlak di lingkungan seperti menanam pohon, menjaga kebersihan, menjaga kelestarian binatang dan tumbuhan.

3. Nilai Amanah dan Ikhlas

Secara etimologi amanah artinya dapat dipercaya dan tanggung jawab. Dalam konteks pendidikan, nilai amanah harus dipegang oleh seluruh pengelola lembaga pendidikan. Sehingga dengan amanah atas tanggung jawab pekerjaan yang diberikan kepada ahlinya, dapat berjalan sesuai pengelolaan yang ditetapkan. Dengan begitu pekerjaan akan mudah sesuai

${ }^{26}$ Faturrohman, Budaya Religius Dalam Peningkatan Mutu Pendidikan, Tinjauan Teoritik dan Praktik Konstekstualisasi Pendidikan Agama Di Sekolah, (Yogyakarta: Kalimemedia, 2015), 61.

${ }^{27}$ Zainuddin Ali, Pendidikan Agama Islam, (Jakarta: Bumi Aksara, 2012), 30.

${ }^{28}$ Zainuddin, Seluk-beluk Pendidikan dari Al-Ghazali, (Jakarta: Bumi Aksara, 1991), 102. 
yang diinginkan. Sedangkan ikhlas diartikan bersih atau hilangnya rasa pamrih atas segala sesuatu yang diperbuatnya. ${ }^{29}$

\section{Nilai Keteladanan}

Nilai keteladanan tercermin dari perilaku guru, keteladanan merupakan hal yang sangat penting dalam pendidikan dan pembelajaran. keteladan ini menjadi suri tauladan yang baik yang dapat dicontoh pada peserta didik. sebagaiman perilaku yang baik dan mencerminkan manfaat bagi semua orang akan memberikan energi yang positif bagi setiap pendidik dalam lingkungan pendidikan.

\section{Nilai Ruhul Jihad}

Ruhul jihad adalah jiwa yang mendorong manusia untuk bekerja atau berjuang dengan sungguh-sungguh. Hal ini didasari adanya tujuan hidup manusia, yaitu Hablum minallah, Hamblum minnas dan Hamblum minal alam. Dengan adanya komitmen ruhul jihad maka aktualisasi diri dan melakukan perkerjaan selalu didasari sikap berjuang dan ikhtiar dengan sungguh-sungguh. ${ }^{30}$ Mencari ilmu merupakan salah satu manifestasi dari sifat Jihad unnafsi yaitu memerangi kebodohan dan kemalasan.

\section{Penanaman Nilai-nilai Religius Dalam Mata Pelajaran Pendidikan Agama Islam}

Latar belakang berdirinya Madrasah Aliyah An-Nur Rambipuji ini dimulai dari rasa kegelisahan yang mendalam dari keadaan atau kondisi sosial dan moralitas masyarakat sekitar yang pengetahuannya terhadap pendidikan menunjukkan minimnya kesadaran bahwa, pendidikan sebagai pintu/gerbang dalam meraih kemajuan sumber daya manusia. Dengan demikian, Madrasah Aliyah An-Nur Rambipuji berdiri tahun 2012, dibawah naungan Yayasan Pondok Pesantren An-Nur Haji Alwi. Pada awal berdirinya, Madrasah Aliyah An-Nur Rambipuji masih berbentuk lembaga non formal yaitu berbentuk sekolah diniyah yang didalamnya diajarkan mata pelajaran agama seperti layaknya sekolah diniyah lainnya atau sekolah di pondok pesantren. Madrasah Aliyah An-Nur Rambipuji tidak terlepas dengan nama KH. Rochmatullah Ali, karena beliaulah sebagai inisiator utama lembaga pendidikan yang setingkat SMA/SMK. Beliau sebagai Pengasuh Pondok Pesantren An-Nur Haji Alwi. Madrasah Aliyah An-Nur Rambipuji sejak berdirinya hingga sekarang terus mengalami perkembangan, yang semula hanya memiliki 3 kelas sekarang

${ }^{29}$ Faturrohman, Budaya Religius Dalam Peningkatan Mutu Pendidikan, Tinjauan Teoritik dan Praktik Konstekstualisasi Pendidikan Agama Di Sekolah, (Yogyakarta: Kalimemedia, 2015), 6o-69.

${ }^{30}$ Faturrohman, Budaya Religius Dalam Peningkatan Mutu Pendidikan, Tinjauan Teoritik dan Praktik Konstekstualisasi Pendidikan Agama Di Sekolah, (Yogyakarta: Kalimemedia, 2015), 62. 
sudah mempunyai 8 kelas. Madrasah Aliyah An-Nur Rambipuji mempunyai satu jurusan, yaitu jurusan Keagamaan. ${ }^{31}$

Berdasarkan hasil temuan dalam observasi yang dilakukan di madrasah Aliyah An-nur Rambipuji menyatakan bahwa, peserta didik dianjurkan sholat dhuha berjamaah sebelum masuk kelas pada pukul 07.30. dengan tujuan peserta didik dapat membiasakan shalat dhuha diwaktu pagi. sehingga diharapkan semuanya dapat menanamkan jiwa atau kedisiplinan bahwa shalat dhuha sebagai bentuk atas rasa syukur yang diberikan kepada Allah SWT, yang telah diberikan kesehatan sampai saat ini. Serta memberikan bentuk keseriusan peserta didik atas pentingnya melaksanakan shalat dhuha tersebut. Maka dengan membiasakan shalat dhuha mudah'an pintu rezeki baik individu maupun orang tua dapat diberikan kelancaran serta kecerdasan bagi semua peserta didik. tidak hanya itu, jika sudah terbiasa maka dengan kesadaran diri sendiri peserta didik dapal melaksanakanya tidak hanya di lingkungan sekolah, akan tetapi akan terbiasa melaksanakan diluar lingkungan sekolah nantinya.

Selanjutnya, sebelum memulai pembelajaran peserta didik juga menerapkan membaca Al-Quran secara bersama-sama terlebih dahulu. Terutama juz 30 yang dibaca, ini bertujuan agar membaca dan menghafal dapat terjalin dengan seutuhnya dalam diri peserta didik. Artinya menanamkan membaca dan menghafal ayat dan makna Al-Quran memberikan daya motivasi dalam belajar dengan bersungguh-sungguh. Dengan memahami makna dan ayat Al-Quran juz 30 dengan membaca berulang-rulang terjaga atau terekam ayat-ayat yang sudah dibaca dan dihafal oleh peserta didik. harapanya juga membiasakan membaca Al-Quran peserta didik dapat mencintai ayat suci Al-Quran dan membiasakan membaca dan memahami maknanya secara mandiri ataupun kelompok baik dilingkungan sekolah di luar sekolah.

Dengan dilaksanakan membaca Al-Quran dilakukan dengan bersamasama dapat memberikan kontribusi membiasakan secara rutin, dilakukan dengan berulang-ulang, terutama peserta didik yang belum mempunyai kesadaran agar lebih tersentuh dalam membaca dan memahami makna ayat Al-Quran. Guna memberikan daya ingat yang sudah dibaca secara berulangberulang.

Berdasarkan hasil penelitian, kegiatan pembelajaran pendidikan agama Islam diterapkan menekankan toleransi satu sama lain dalam menyampaikan pendapat satu sama lain. Gagasan-gagasan dalam berpendapat menyampaikan pemahaman isi materi diberikan kebebasan dalam memahaminya secara individu. Sehingga peserta dapat berkreasi dalam menyampaikan pendapat masing-masing. Sehingga peserta didik, satu sama lain dapat menghargai gagasan-gagasan dari masing-masing individu. Penanaman toleransi ini,

\footnotetext{
${ }^{31}$ MA An-Nur Rambipuji, “Sejarah MA An-Nur Rambipuji,” 11 Januari 2021.
} 
sebagai bentuk saling menghormati/menghargai dalam berpendapat baik dalam wilayah kecil maupun besar. Sehingga penamaman toleransi ini dapat memberikan komunikasi yang baik antar peserta dalam berpendapat. Dengan adanya penanaman toleransi ini agae jiwa peserta didik tidak ada saling membenci atau melukai dengan adanya kesadran dalam toleransi dalam berpendapat. Karena dengan hal ini, sangat perlu diperhatikan serta ditanamkan dalam diri masing-masing peserta didik. bahwa sekecil apapun pendapat yang disampaikan oleh sesama muslim atau non muslim perlu kita hargai. ${ }^{32}$

Kegiatan pembelajaran dengan menekankan toleransi berpendapat, menjadikan peserta didik dapat mandiri dalam belajar dengan memahami materi pembelajaran sesuai dengan pola pikir/gagasan masing-masing. Hal ini bertujuan dapat mengembangkan daya berfikir belajar peserta didik dengan materi pembelajaran yang ditentukan. Bahwa, pembelajaran dengan kebiasaan seperti ini, diharapkan semua peserta didik membiasakan dan menanamkan dalam jiwa diri sendiri pentingnya toleransi antar sesama baik dilingkungan sekolah maupun di luar sekolah kedepanya.

Berdasarkan hasil observasi, terdapat pembiasaan sikap yang perlu di terapkan dalam kebiasaan sehar-hari baik di lingkungan sekolah atau keluarga maupun masyarakat kedepan. Seperti penanaman nila-nilai religius dalam kegiatan ${ }_{3} \mathrm{~S}$ (senyum, sapa, salam), yang diprogramkan guru pendidikan agama Islam. kebiasaan ini diharapkan menjadi budaya nantinya, yang selalu tertanam dalam jiwa peserta didik baik di sekolah maupun luar sekolah. Sehingga ketika bertemu dengan guru maupun masyarakat, sala,sapa, senyum ini dapat menjadikan kebiasaan yang baik dalam diri peserta didik. ${ }^{33}$

Maka dengan senyum, salam, sapa konsep akhlak terhadap guru terutama dapat bener-bener terealisasi dalam penanaman nilai-nilai religius itu sendiri. agar peserta didik dapat memahami bahwa hal sekecil dalam kegiatan yang dilakukan disekolah menunjukkan makna yang dapat diambil dari kegiatan itu sendiri. kebiasan-kebiasaan yang sebelumnya tidak terjalin dengan adanya penanaman nilai-niai religius guru pendidikan agama Islam ini sangat membantu dan menjadikan kebiasaan tersebut dapat terus terjalin serta memancarkan energi positif bagi para peserta didik. Dengan demikian, ini mendedikasikan bahwa keteladanan telah diberikan sebagi bentuk kebiasaan-kebiasaan yang dilakukan peserta didik dalam menjalankan aktivitas-aktivitas dalam pembelajaran. demikian juga memberikan kesan yang positif dalam menjalankan kebiasaan yang dilakukanya. ${ }^{34}$

Berdasarkan hasil observasi yang dilakukan, setiap hari jumat dilaksanakan untuk infaq seikhlasnya secara bersama-sama baik peserta didik

\footnotetext{
${ }^{32}$ Syaifan Shodiq, diwawancara oleh Penulis, 5 Agustus 2021.

${ }^{33}$ Shidiq. diwawancara oleh penulis, Jember, 5 Agustus 2021.

${ }^{34}$ Ahmad Zayyinul Musthofa, diwawancar oleh Penulis, Jember, 6 Agustus 2021.
} 
maupun guru. dengan tujuan agar rezeki yang kita dapatkan dapat menjadi barokah saat dibagikan kepada orang yang membutuhkan. Sehingga infaq untuk setiap hari jumat agar dapat memberikan kelancaran dan kesehatan bagi para peserta dalam menempuh pembelajaran yang dilaksanakan. bahwa, sebagai bentuk rasa kepedulian bagi yang berhak menerimanya atas kebiasaan infaq/sedekah yang dibiasakan setiap hari jumat. Sebab itu kegiatan dalam penanaman nilai-nilai religius dapat diimplementasikan atau diselipkan dalam kegiatan pembelajaran agar hablum minannas dan hablum minallah dapat terjalin erat dalam jiwa masing-masing individu.

Menurut Nurcholis Madjid, suasana religius yang berbentuk ritual dan simbolik dianggap sebagai "bingkai" atau "kerangka", sebab itu ritus (kegiatan keagamaan) dan formalitas bukanlah tujuan, ia akan baru memiliki makna yang hakiki jika menghantarkan orang yang bersangkutan kepada tujuannya yang hakiki, yaitu kedekatan (taqarrub) kepada Allah dan kebaikan kepada sesama manusia (akhlak karimah). ${ }^{35}$

Selain itu dalam menanamkan nilai religius ini bertujuan menciptakan situasi atau keadaan religius. Tujuannya untuk mengenalkan kepada anak didik tentang pengertian agama dan tata cara pelaksanaan agama tersebut dalam kehidupan sehari-hari. Selain itu juga menunjukkan pengembangan kehidupan religius di lembaga pendidikan yang tergambar dari perilaku sehari-hari dari berbagai kegiatan yang dilakukan oleh guru dan anak didik. Oleh karena itu keadaan atau situasi keagamaan di sekolah yang dapat diciptakan antara lain pengadaan peralatan peribadatan seperti tempat untuk shalat (masjid atau mushalla), alat-alat shalat seperti sarung, peci, mukena, sajadah atau pengadaan al-Quran. Selain itu di ruangan kelas bisa pula ditempelkan kaligrafi, sehingga anak didik dibiasakan selalu melihat sesuatu yang baik. Selain itu dengan menciptakan suasana kehidupan keagamaan di sekolah antara sesama guru, guru dengan anak didik, atau anak didik dengan anak didik lainnya. Misalnya, dengan mengucapkan kata-kata yang baik ketika bertemu atau berpisah, mengawali dan mengakhiri suatu kegiatan, mengajukan pendapatan atau pertanyaan dengan cara yang baik, sopan, santun tidak merendahkan anak didik lainnya, dan sebagainya.

Serta dalam mengembangkan kemampuan peserta didik dari segi keagamaan terutama di Madrasah Aliyah An-Nur Rambipuji ini memberikan kesempatan kepada peserta didik untuk mengekspresikan diri, menumbuhkan bakat, minat dan kreativitas pendidikan agama dalam keterampilan dan seni, seperti membaca al-Quran, adzan, sari tilawah, serta untuk mendorong anak didik sekolah mencintai kitab suci, dan meningkatkan minat anak didik untuk membaca, menulis serta mempelajari isi kandungan al-Quran. Dalam membahas suatu materi pelajaran agar lebih jelas guru hendaknya selalu diperkuat oleh nas-nas keagamaan yang sesuai

\footnotetext{
${ }^{35}$ Nurcholis Majid, Masyarakat Religius, (Jakarta: Paramedina, 1997), 128.
} 
berlandaskan pada al-Quran dan Hadits Rasulullah saw. Tidak hanya ketika mengajar saja tetapi dalam setiap kesempatan guru harus mengembangkan kesadaran beragama dan menanamkan jiwa keberagamaan yang benar. Guru memperhatikan minat keberagaman anak didik. Untuk itu guru harus mampu menciptakan dan memanfaatkan suasana keberagamaan dengan menciptakan suasana dalam peribadatan seperti shalat, puasa dan lain-lain.

Seorang guru profesional baik yang sudah bersertifikasi atau pun yang belum sertifikasi dalam memberikan pembelajaran tidak hanya transfer kenowledge melain nilai-nilai (value) keteladan baik sosial atau pun pribadi yang tertanam dalam seorang guru itu sendiri. Sikap dan keteladanan yang ditunjukkan seorang pendidik dalam memberikan pembelajaran yang baik akan mampu memberikan nilai positif dan perubahan dalam diri pribadi peserta didik. Tindak tanduk, perilaku, ucapan, bahkan gaya mengajar pendidik, serta interaksi proses pelayanan peserta didik pun akan sulit dihilangkan dalam ingatan peserta didik. Begitu pula karakter kepribadian pendidik dan pegawai juga selalu terekam dan membekas dalam memori peserta didik.

Satu teori yang menarik untuk dikaji bahwa satu teori kognitif sosial yang sangat efektif adalah teorimodeling. Istilah modelling berarti adanya suatu proses peneladanan, peniruan terhadap subyek atau model oleh individu atau kelompok. ${ }^{36}$ Hal senada diungkapkan oleh Misdar menurut teori tersebut seorang guru atau siswa adalah orang yang dapatberperan sebagai model, perilaku yang dimunculkan saling berinteraksi denganlingkungan. ${ }^{37}$

Aktivitas rutin salat dhuha berjamaah dilakukan bukan hanya oleh peserta didik, tetapi guru, kepala sekolah, dan seluruh sivitas akademika di Madrasah Aliyah An-Nur Rambipuji juga erlibat dan tak lupa pula pengasuh pondok pesantren AN-Nur.. Demikian juga aktivitas membaca Al-Quran dan perilaku yang berakhlakul karimah. Ketiga aktivitas tersebut melibatkan seluruh komponen sekolah. Guru sebagai orang tua di sekolah, kepala sekolah, maupun sivitas akademika lainnya di sekolah berperan menjadi contoh perilaku terbaik (teladan).

Adanya pembiasaan aktivitas rutin, dan keteladanan yang ditampilkan oleh guru, kepala sekolah, dan sivitas akademika merupakan salah satu cara penanaman karakter pada peserta didik ketika berada di sekolah. Peserta didik pada usia sekolah dasar sedang berada pada tahap meniru. Sehingga keteladanan yang ditampilkan merupakan langkah efektif dan efisien bagi penanaman karakter peserta didik. Bandura, ${ }^{38}$ mengemukakan bahwa

\footnotetext{
${ }^{36}$ Yuliyatun Tajudin, Islam Dan Masyarakat Modern Dalam Sistem Modeling Masyarakat Jawa. Jurnal Community development. Volume 1, No. 1, Juni 2016, 39.

${ }^{37}$ Muh Misdar, Keteladanan Guru Dalam Pembelajaran, JurnalAtTa'lim, Vol. 15, No. 1, Januari 2016, 2.

${ }^{38}$ Robert E. Slavin, Psikologi Pendidikan Teori dan Praktik, (Jakarta: Indeks, 2011), 202-203.
} 
pembelajaran manusia tidak dibentuk oleh konsekuensinya tetapi dipelajari dengan lebih efisiensi langsung dari suatu model (peniruan). Peniruan ini melalui empat tahap yakni tahap perhatian, pengingatan, reproduksi, dan motivasi. Peserta didik akan memperhatikan contoh guru ketika salat dhuha, membaca Al-Quran, dan berperilaku berdasarkan akhlakul karimah, dengan mempraktikkannya dan mereproduksinya. Strategi peniruan ini sesuai dengan pernyataan yang dikemukakan oleh Gunawan ${ }^{39}$ bahwa faktor intern yang mempengaruhi karakter peserta didik adalah adat atau kebiasaan.

Pendidikan karakter pada dasarnya dilaksanakan untuk menanamkan kebiasaan-kebiasaan baik kepada peserta didik. Pembiasaan-pembiasaan yang disusun oleh pihak sekolah untuk menanamkan nilai-nilai keagamaan sejalan dengan pernyataan Lickona, ${ }^{40}$ yang menyatakan pendidikan karakter adalah upaya yang dilakukan dengan sengaja untuk mengembangkan karakter yang baik (good character) berdasarkan kebajikan-kebajikan inti (core virtues) yang secara objektif baik bagi individu dan masyarakat. Dengan begitu sekolah bisa menyusun sendiri daftar mengenai nilai-nilai yang ingin ditumbuhkembangkan melalui pendidikan karakter.

Pembiasaan yang dilakukan secara terus-menerus diharapkan peserta didik akan memiliki kesadaran, kepedulian, dan terbiasa menerapkan hal-hal kebaikan dalam kehidupan sehari-hari. Dengan demikian perilaku sehari-hari peserta didik tidak terlepas dari nilainilai religius. Pernyataan tersebut sejalan dengan pendapat yang dikemukakan oleh Sudewo, ${ }^{41}$ karakter dapat didefinisikan sebagai kumpulan sifat baik yang menjadi perilaku sehari-hari. Perilaku sehari-hari tersebut dapat berupa perwujudan kesadaran menjalankan peran, fungsi, dan tugas dalam mengemban amanah dan tanggung jawab.

\section{Kesimpulan}

Kompetensi guru sebagai bentuk yang tertanam dalam diri pribadi seorang guru dalam segi, pengetahuan, keterampilan dan kemampuan yang sebaiknya dapat dilakukan seorang guru dalam melaksanakan pekerjaannya. Nilai religius sebagai salah satu nilai karakter yang dijadikan sebagai sikap dan perilaku yang patuh dalam melaksanakan ajaran agama yang dianut, toleran terhadap pelaksanaan ibadah agama lain, dan hidup rukun dengan pemeluk agama lain. Karakter religius ini sangat dibutuhkan oleh siswa dalam menghadapi perubahan zaman dan degradasi moral seperti saat ini. Dalam hal ini peserta didik diharapakan mampu memiliki dan berperilaku dengan

${ }^{39} \mathrm{H}$ Gunawan, Pendidikan Karakter Konsep dan Implementasi, (Bandung: Alfabeta, 2012), 19-20.

${ }^{40}$ Saptono, Dimensi-dimensi Pendidikan Karakter Wawasan, Strategi, dan Langkah Praktis, (Jakarta: Esensi Erlangga Group, 2011), 55.

${ }^{41}$ E Sudewo. Best Practice Character Buliding Menuju Indonesia Lebih Baik, (Jakarta: Republika Penerbit, 2011), 14. 
ukuran baik dan buruk yang didasarkan pada ketentuan dan ketetapan agama. Kegiatan pembelajaran dengan menekankan toleransi berpendapat, menjadikan peserta didik dapat mandiri dalam belajar dengan memahami materi pembelajaran sesuai dengan pola pikir/gagasan masing-masing. Hal ini bertujuan dapat mengembangkan daya berfikir belajar peserta didik dengan materi pembelajaran yang ditentukan. pembiasaan sikap yang perlu di terapkan dalam kebiasaan sehar-hari baik di lingkungan sekolah atau keluarga maupun masyarakat kedepan. Seperti penanaman nila-nilai religius dalam kegiatan ${ }_{3} \mathrm{~S}$ (senyum,sapa,salam), yang diprogramkan guru pendidikan agama Islam.

\section{Daftar Pustaka}

Ahmad, Abu dan Noor Salim. 2008. Dasar-Dasar Pendidikan Agama Islam. Jakarta: Bumi Aksara.

Ali, Zainuddin. 2012. Pendidikan Agama Islam. Jakarta: Bumi Aksara.

Bahasa Departemen Pendidikan Nasional, Pusat. 2003. Kamus Besar Bahasa Indonesia. Jakarta: Balai Pustaka.

E. Slavin, Robert. 2011. Psikologi Pendidikan Teori dan Praktik. Jakarta: Indeks.

Faturrohman. 2015. Budaya Religius Dalam Peningkatan Mutu Pendidikan, Tinjauan Teoritik dan Praktik Konstekstualisasi Pendidikan Agama Di Sekolah. Yogyakarta: Kalimemedia.

Fauzi, Imron. 2017. Etika Profesi Keguruan. Jember: IAIN Jember Press.

Gunawan, H. 2012. Pendidikan Karakter Konsep dan Implementasi. Bandung: Alfabeta.

Huberman, Miles dan Saldana. 2014. Qualitative Data Analysis. America: SAGE Publications.

MA An-Nur Rambipuji. 2021. "Sejarah MA An-Nur Rambipuji,” 11 Januari.

Majid, Nurcholis. 1997. Masyarakat Religius. Jakarta: Paramedina. 
Misdar, Muh. 2016. Keteladanan Guru Dalam Pembelajaran, JurnalAtTa'lim, Vol. 15, No. 1, Januari.

Moleong, Lexy. 2010. Metodologi Penelitian Kualitatif . Bandung: PT Remaja Rosdakarya.

Mulyasa, E.. 2013. Standar Kompetensi dan Sertifikasi Guru. Bandung: PT Remaja Rosdakarya.

Musfah, Jejen. 2012. Peningkatan Kompetensi Guru : Melalaui Pelatihan dan Sumber Belajar Teori dan Praktik. Jakarta: Kencana.

Muslich, Mansur. 2011. Pendidikan Karakter, Menjawab Tantangan Krisis Multidimesional. Jakarta: PT Bumi Aksara.

Novauli. M, Feralys. 2015. "Kompetensi Guru Dalam Peningkatan Prestasi Belajar Pada SMP Negeri Dalam kota Banda Aceh", Jurnal Administrasi Pendidikan 3, no. 1 februari.

Pendidikan Nasional, Depatemen. 2006. Undang-Undang Republik Indonesia, No. 14 Tahun 2005 Tentang Guru dan Dosen.

Saptono. 2011. Dimensi-dimensi Pendidikan Karakter Wawasan, Strategi, dan Langkah Praktis. Jakarta: Esensi Erlangga Group.

Shidiq. 2021. diwawancara oleh penulis, Jember, 5 Agustus.

Shodiq, Syaifan. 2021. diwawancara oleh Penulis. 5 Agustus.

Situmorang, J. B dan Winarno,. 2008. Pendidikan Profesi dan Sertifikasi Pendidik. Klaten: Macanan Jaya Cemerlang.

Solikah, Alfiatu. 2019. Strategi Peningkatan Mutu Pembelajaran Pada Sekolah Unggulan. Yogyakarta: CV Budi Utama.

Sudewo. E. 2011. Best Practice Character Buliding Menuju Indonesia Lebih Baik. Jakarta: Republika Penerbit.

Sugiyono. 2014. Metode Penelitian Pendidikan Pendekatan Kuantitatif, Kualitatif, Dan RED. Bandung: Alfabeta. 
Suprihatiningkrum, Jamil. 2014. Guru Profesional : Pedoman Kinerja, Kualifikasi E Kompetensi Guru. Yogyakarta: Ar-Ruzz Media.

Suyanto dan Asep Jihad. 2013. Menjadi Guru Profesional: Strategi Meningkatkan Kualifikasi dan Kualitas Guru di Era Globalisasi. Jakarta: Erlangga.

Tajudin, Yuliyatun. 2016. Islam Dan Masyarakat Modern Dalam Sistem Modeling Masyarakat Jawa. Jurnal Community development. Volume 1, No. 1, Juni.

Wibowo, Agus dan Hamrin. 2012. Menjadi Guru Berkarakter: Strategi Membangun Kompetensi dan Karakter Guru. Yogyakarta: Pustaka Pelajar.

Zainuddin. 1991. Seluk-beluk Pendidikan dari Al-Ghazali. Jakarta: Bumi Aksara.

Zayyinul Musthofa, Ahmad. 2021. diwawancar oleh Penulis. Jember. 6 Agustus.

Zubaidi. 2011. Desain Pendidikan Karakter. Jakarta: Prenada Media Group. 